\title{
The Madrasah Leadership, Teacher Performance and Learning Culture to Improve Quality at Madrasah Tsanawiyah Negeri Jakarta of South
}

\author{
Noor Muhammadi ${ }^{1}$, Shahrir Charil bin Hj. Marzuki ${ }^{2} \&$ Mohd. Yahya bin Mohd. Hussin ${ }^{2}$ \\ ${ }^{1}$ STIA YAPPANN Jakarta, Indonesia \\ ${ }^{2}$ UPSI Tanjung Malem Perak Malaysia, Malaysia \\ Correspondence: Noor Muhammadi, Lecture of STIA YAPPANN Jakarta, Indonesia. E-mail: \\ noormuh01@gmail.com
}

Received: March 25, 2015 Accepted: April 10, 2015 Online Published: May 31, 2015

doi:10.5539/jms.v5n2p129 URL: http://dx.doi.org/10.5539/jms.v5n2p129

\begin{abstract}
The aim of this study was to analyze the impact of the madrasah leadership, teacher performance and learning culture with madrasah quality. The research objectives to be achieved are: Identify the level of the madrasah leadership, teachers performance, learning culture and the quality of the madrasah; Identify the relationship of the madrasah leadership with madrasah quality; Identify the relationship of the teacher performance with madrasah quality; Identify the relationship of the learning culture with madrasah quality; Identify the relationship model of the of madrasah leadership, teacher performance and learning culture with madrasah quality. The design of this study is quantitative research methods with methods of descriptive and inferential. This study applies a survey method to collect quantitative data through questionnaires. The findings of this study that there is a correlation between madrasah leadership are quality madrasah. There is a relationship to the teacher performance with quality of madrasah. There is a relationship to the learning culture with quality of madrasah. There is a relationship model of madrasah leadership, teacher performance and learning culture of the quality of madrasah. Therefore, based on the results of this study to produce high madrasah quality can be done by improving of the leadership of madrasah, teacher performance and learning culture in madrasah. If the leadership of madrasah, teacher performance and learning culture is low, it will result a lower quality in madrasah.
\end{abstract}

Keyword: leadership, teachers performance, learning culture, quality

\section{Introduction}

Society demands madrasah as a formal educational institutions based on religion in a planned and strategic must be able to improve the quality of educational activities, especially in terms of internal, namely personal manager especially headmaster and teachers and other education personnel. Headmaster is the deciding factor (determinant) success in the management of madrasah to improve students' academic achievement and skills. Headmaster also plays a role in the process of planning, organizing, implementing, directing and leading all association programs and lists all power sources in order to achieve the objectives set. As a manager with its cleverness and intelligence seek and strive various interrelated activities to achieve objectives.

According to Senge et al. (1990) as noted from Marks \& Printy (2003) explained that schools or madrassah remain depend on the leadership of the organization to anticipate future productive through the reform process itself. Human resources in educational institutions, especially schools, can be improved by the help of the headmaster. The headmaster is a holder of human resource management at the school. The headmaster should give serious thought to undertake the development of human resources at the schools. Reviews Goldring and Pasternak in Youngs \& King (2002) found that the perpetrator may indirectly affect the achievement of having established a mission or a set of goals and build commitment covering the whole school, or madrasah. Barnett and McCormick (2004) proved that the dean of leadership effects on student achievement is through school conditions such as purpose, structure, and culture of the school. Mulyasa (2003) said that headmaster has the power in government schools (madrasah). The school principal plays as educators, managers, administrators, supervisors, leaders, innovators and motivators. The role of headmaster regarded as a person who plays an important role in ensuring the effectiveness and efficiency of school in the running of schools. Newmann, King and Youngs in Fullan (2002) explain that headmaster must be a teaching leader if he wants to be an effective 
leader in defense reform. Sergiovani (2001) says in many school principals are the most important and influential individual in any school. It is his leadership that sets the tone of the school, the climate for learning. The level of profesionalism and morale of teacher and the degree of concern for what students may or may not become.

Witziers, Bosker and Kruger (2003) reported the findings of a positive value effect in the meta-analysis reinforces born earlier studies on the limitations of the impact of a direct approach to linking leadership with student achievement. This study discass the effect of leadership behaviors including the following seven aspects that define and deliver mission, supervising and evaluating the curriculum, monitor student progress, connect and manage the curriculum, the presence of the head, promoting the development of the school and professional development and achievement of the orient. From these studies, it appears that success depends on the madrasah or school head. This is due madrasah or school administrator may require awareness of the goals and objectives madrasah or school; set high expectations among staff and students, focus efforts techniques improving teaching and learning as well as monitoring the performance and encourage staff to provide the best contribution (Blandford, 2004).

Suratman (2009) said headmaster leadership is one of the factors that determine the level of student achievement so headmaster required to have the ability to lead adequate to be able to take the initiative of improving the quality of madrasah. According to Rahimah (2003) the practice of leadership behavior throughout the 'core business' schools are teaching and learning. The important aspect is the increasing professionalism of teachers and staff and behaviors that describe tribute to their professionalism. Thus, it can be said the high professionalism of teachers and school staff in madrasah or marked by the quality of leadership headmaster.

According to Mulyasa (2006), a competent teacher is an educator who become leaders, role models and the identity of the student and their environment. Teachers should have a certain standard of quality that include personal responsibility, power, and self-discipline, demands aimed at improving the quality of teachers, teachers always improve his performance. Teacher activity as teachers will continue to grow if the coach is always motivated to excel in performing their duties and responsibilities.

Further disclosed that: "the quality of education as assessed student achievement is determined by the teacher, which is $34 \%$ in developing countries and $36 \%$ in the industrialized countries" Supriya (1998). Madrasah teachers at this time can be divided into three categories, first, the teacher is not feasible which can be categorized as unqualified or underqualified. This means that the teachers do not have a teaching qualification as prescribed by applicable law. For example, to teach teachers have at least a diploma D-4 or S-1 This requirement has not been met. Second, the teacher deserves but one profession (mismatch). That is not the appropriate educational background / teaching Natural Sciences Social Sciences. Third, decent and appropriate professional teacher taught study. Graduate-level teacher education in accordance with applicable regulations, and when viewed in the data Madrasah teachers today, nearly $60 \%$ of teachers madrasah unfit category and number to $80 \%$ in the private madrasah. Rahim (2005) The incoming decent but one profession as much as $20 \%$ in the madrasah, and the remaining $20 \%$ were actually decent and appropriate professions taught study. There are many teachers who do not have a good performance. According to Mulyasa (2007), there are at least seven indicators of poor performance of teachers in carrying out teaching duties, namely: (a) lack of understanding of learning strategies, (b) lack of skills in management class, (c) lack of ability to conduct research and utilize class action, (d) low achievement motivation, (d) lack of commitment to the profession, (e) for the low ability of time management.

Uwes (2004) said that the weakness of Islamic educational institutions are less capable and can not compete with other educational institutions is due to lack of institutional organizational skills. From these statements it appears that madrasah as Islamic educational institutions it has not been able in the management of educational institutions with well, both with regard to the quality of human resources, learning and other management.

Accorrding to Subandi (2010) that most of the headmaster and teachers have not been able to innovate in planning, implementing and improving madrasa-based curriculum. From these studies it appears that there are many principals and teachers who have not been able to carry out their duties and functions well. According to Kumandar (2007) that one of which is the educational staff morale is low thereby affecting acceleration capabilities that require mastery of academic staff in accordance with the demands of the development of science and technology and the new curriculum. In fact, the demands on the performance of the headmaster is still not been met, as there are many madrasahh underachieving students, student indiscipline, so it requires leadership patterns to affect student achievement in developing quality madrasah. leadership headmaster has an emphasis in management madrasah and expected headmaster will be able to increase student achievement in developing the quality of madrasah.

This review aims to identify the quality of the madrasah, from three aspects: leadership, teacher performance, 
cultural study of the quality of madrasah. In particular, the objectives of this research is to analyze the impact of leadership dean, teacher performance and learning cultureof the quality of madrasah. Objectively research to be achieved is to: identify the level of leadership headmaster, teacher performance at the school, the culture of learning and the quality of madrasah; identify the relationship of the quality of school leadership madrasahh; identify the relationship of teacher performance against quality madrasah; identify the relationship of culture to learn to quality madrasah; identify the model of leadership relationship headmaster, teacher performance and learning cultureof the quality of madrasah.

\section{Literature Review}

\subsection{Madrasah Principals Leadership}

Headmaster is a leader or manager madrasah leadership organization is the ability to control or influence another person or society that differ from each other against certain achievement (Arep \& Tanjung, 2003). This definition shows that the interests of leadership within the organization to achieve organizational goals can be met. Bafadhal (2003) defines leadership as a whole process to influence, encourage, engage, mobilize and guide others in the work process in order to think, behave, act in accordance with the applicable rules in order to achieve the goals set, from the above it is the leadership behavior of leaders describe the dynamics of the real leaders of a person based on his leadership.

Lako (2004), in his book concludes leadership is a process to direct and influence the activities of the group members, provide vision, joy, excitement, love, trust, passion, obsession and consistency to the members of the organization and the use of symbols, giving attention, showing examples or real action, produce heroes at all levels of the organization, and provide effective training to members of the organization. Headmaster is one of the most important aspects in the madrasah, in the lead and set the tone madrasah, because the process of teaching and learning good leadership can run well. Good leadership, teachers, administrative staff and students can enjoy the atmosphere that can improve work performance madrasah teachers, administrative staff and improving student achievement.

This was affirmed by the Mulyasa (2002) said that leadership is very important in the school-based management. The behavior of the principal should be able to push the performance of the teachers to show a friendly, close, and full consideration of the teachers, both as individuals and as a group. The effectiveness of leadership is now measured by the ability of leaders to change behavior and take care of school leadership in a variety of contexts and situations Bolman and Granell (1999). Additionally, Portin et. al., (2003) found leadership assessment requires in-depth study based on the type of school because each school requires leadership behavior different. Mulyono (2008) said that, headmaster must have the ability to be able to bring educational institutions or to improve the quality of education. That is effective in terms of School-Based Management (SBM), has a basic education and insight, understanding the school as a system, understanding the teaching and learning standards, planning construction of schools, curriculum, management, managing staff, taking care facilities and infrastructure, which manages student affairs, which brings madrasah.

Mulyasa (2004), says: "dean as manager means all abilities in managing resources to achieve the goal of educational institutions through the effective and efficient management functions, by acting in: 1) Develop a program, 2) Develops a staff organization, 3) moving staff, and 3) Optimize HR ". Oliver (2008) divides the behavior and leadership styles into four systems, namely: charisma, individual consideration, intellectual stimulation, motivation inspiration. Similarly, Avolio et. al., (1999: 448) who develops a critical approach to perform its role as a leader and consists of: (1) idealized influence, (2) inspirational motivation, (3) intellectual stimulation and (4) consideration of the individual. Headmaster has duties and functions to coordinate and harmonize human resources through a number of management inputs in order to use its expertise to intervene with other sources. Teaching and learning can take place properly to produce the expected output.

\subsection{Teachers Performance}

According to the Law of the Republic of Indonesia No. 14 Year 2005 on Teachers and lecturers: teachers are professional educators with the primary task of educating, teaching, guiding, directing, train, assess and evaluate students in early childhood education, elementary education and secondary education. In Act No. 14 of 2005 explained that: "Teachers have a position as professionals in primary education, secondary education, and early childhood education in formal education are appointed in accordance with legal regulations.

According to Kusnadi (2002) teachers performance is a movement, action, implementation, activities or actions consciously directed to achieve something specific goals or targets, in carrying out its activities or as a responsibility towards the tasks and duties assigned to him. Robbins (2001) said that the performance is a 
measure of the work done by describing the criteria that have been agreed. The performance of individuals or groups within the organization have a criteria or a certain size, this means that the appearance of the work is not limited to staff who took office functional and structural, but also to the entire line of the staff in the organization. The underlying theory is a theory of teacher performance raised by Sally Wehmeier (2000) are the things that relate to something that has been done, whether he is male or female him. Kast and Rosenzweig (1985) provide a general concept of performance is: performance $=f$ (willingness, effort and opportunity). This equation has the principal factors or variables that produce performance, inputs (inputs), will determine the outcome of individual and group efforts. Ability is a function of knowledge and skills of human and technological capabilities. Effort is a function of the needs, objectives, expectations and rewards. Ppportunity to the teachers in their personal development.

According Supriatno (1996) mentions that the aspects that can be used to evaluate job performance or achievements include: 1) the planning of teaching, 2) delivery, 3) diversification of teaching methods, 4) meet different needs, 5) evaluation and reporting.

Teacher performance can also be shown by how much the desired competencies are met. "Competence includes pedagogical competence, personal competence, social competence and professional competence" (Law No. 14 of 2005 on Teachers and Lecturers).

Teacher performance can be seen clearly in the teaching-learning process he displays of student achievement. The quality of teaching is an aspect of the efforts of teachers to deliver instruction that is easy to understand, easy to remember and fun. Teachers need to deliver teaching materials are structured and systematic Kallison (1986).

\subsection{Learning Cultural}

A learning cultureis a set of values, norms, assumptions, beliefs, principles, rules and norms or rules in the learning process that regulate and direct the behavior of students and teachers in an effort to make the learning process at the school. Cultural actually describes the attitude, which is realized through an example from above and reflected in the rules and procedures of formal organizations such as Madrasah.

Tilaar (2002) mentions that the aspects that can be used to assess learning cultureamong others, the value of education, emphasis on learning, equalization missions, teacher. Cultural values as stated by Koentjaraningrat (2002) is a concept that lives in the minds of many residents, about the things that they consider very valuable in life and cultural value system, which is an abstract, usually serves as the supreme guide for human behavior. Gibson (2003) defines culture is a culture containing explicit or implicit patterns and to conduct the necessary and embodied in symbols, shows the results of different human groups, including the objects of human creation, the main core of culture consists of traditional ideas (hereditary and selected) and especially on historiography value (historicity).

According to Halpin and Croft (1963) which is a pioneer in the study of learning culturein schools or madrasah said at least nine factors that must be defined in explaining the culture of schools or madrasah, including economic background in the school's teachers, parents' attitudes towards madrasah, physical condition madrasah and social interaction between the head and the madrasah teacher, he also has introduced a research instrument called "Organizational Climate Description Qustionnaire" (OCDQ) as a tool to measure the conditions that exist in schools or madrasah which was later renamed as the organizational culture of the school or madrasah. Taiguri (1998) one of the underlying theoris or models of a learning cultureis a theory or model of the environment. Theory or model is promoted that culture exists in an organization, including in madrasah that form the culture of learning consists of: ecology, milieu, social systems and cultural organizations madrasah.

Underlying theory or model of a learning cultureis a culture model madrasah Cavanagh \& Dellar (2000), Cavanagh and Ramanoski (2005) saw eight cultural factors in improving madrasah towards achievement of the students' academic achievement. This model describes the relationship between the five factors in the learning culture madrasah, ie the value of education, leadership, emphasis on learning, teacher, cooperation, equalization vision and teacher efficacy. In a culture of learning at the school values and norms will evolve when teachers interact with each other, personal interaction between teachers provide the opportunity for individuals to accommodate the needs and confidence and attitudes of teachers. In this exchange process does not take place, the teacher will be in a situation of isolation and culture of learning at the school would not exist.

\subsection{Madrasah Quality}

Madrasah as Islamic educational institutions in Indonesia is relatively young compared to boarding Fajar (1998). Steenbrink (1994) Madrasah stood on the initiative and consciousness of the update of the Islamic education 
system already exist, such reforms, according Steernbrink (1998), includes three cases, namely: business perfect cottage madrasah education system, adjustments to the western education system, and businesses close up between the traditional education system and the system of western education.

Madrasah education is a reality that accommodate the aspirations of socio-cultural-religious Indonesian Muslim population that is culturally rooted in the community, in order to realize the vision and mission of madrasah in raising achievement and education in madrasah, the target in the development of qualities of madrasah is education stakeholders, including the public and guardians of students, construction qualities of madrasah, will give a good impression of a positive for the competitiveness of the madrasah, achievement although teacher qualities of graduates. The work program madrasah, a working basis madrasah component in the learning process activities conducted in madrasah. Tthe program was awoken by the rules and assessment conducted by the Ministry of Religious Affairs as the parent body of the organization madrasah

Related to the quality, according to Besterfield, et. al., (2003) gives the formula of the qualities, namely the qualities is the performance divided by expectations. Quality is something that is dynamically follow the dynamic of customers and the environment. Goetsch and Davis (2006) said "Quality is a dynamic state associated with products, services, people, processes, and environments that meets or exceeds expectations". David (2006) said that the qualities visible than some aspects ie, of dean madrasah strong leadership and effective, healthy school climate conducive emphasis on proficiency principle, high expectations for student academic achievement.

Ishikawa (2001), which is often regarded as the maintenance of the qualities of Japanese experts to define the qualities as follows: "(1) quality and customer satisfaction are the same thing, and (2) quality is a broad concept that goes beyond just product quality to Also include the quality of people, processes, and every other aspect of the organization". It can be concluded that the quality of madrasah is generated achievement educational institutions (madrasah) in order to fulfill the needs of customers satisfaction and that the community and parents on the quality of the learning process in schools with the goal of improving student academic achievement and personality of students in accordance with the guidance of religion, by utilizing existing resources at the school effectively and efficiently.

\section{Research Methods}

The study design was conducted by the method of quantitative research with descriptive and inferential methods. This study design is used as the main focus of this study is the relationship between leadership headmaster and teacher performance and learning culture of the quality of madrasah, opinions Kerlinger (2004) states: "Methods of quantitative review The most suitable to see the relationship between the variables ".

According to Chua (2006) descriptive statistics have been used to explain or elaborate on the characteristics of variables using symbols such as min, standard deviation, and the percentage of the normal distribution. Instead, statistical inference has been used for research in the form of correlation and this review uses a quantitative approach, researchers used questionnaires to collect quantitative data research. According to Babbie (2001) quantitative method is the best tool to collect valid data from a large population through sampling techniques, research is an appropriate and useful tool to gauge the opinion, attitudes, perceptions and behaviors or subjects, this research begins with the collection of quantitative data, followed by data analysis to obtain results.

This review method review to gather quantitative data using a questionnaire study. It is a tool to examine the relationship between independent and dependent variables, review involves the collection of data from a representative sample of the population at any period. This review using a questionnaire, the questionnaire is used as a primary research tool to collect information about factors school leadership, teacher performance and learning culture in improving the quality of madrasah. Reviews are limited in seven districts or regions in South Jakarta. To ensure the smooth process of data collection, the research conducted in the district of South Jakarta, namely: Kebayoran Lama, Pasar Minggu, Mampang Prapatan, Pesanggrahan, Cilandak, Jagakarsa, Pasar Rebo. The sample in this study is a teacher at the South Jakarta District MTs as many as 200 people. To determine the sample used random sampling means that samples taken at random. Sampling of 200 respondents was based on the opinions according to Sugiarto (2003) simple random sampling method is a method used to select a sample of the population in such a way that every member of the population has an equal chance to be taken as a sample. While Gay and Airasian (2000) showed that $10-20 \%$ of the population sample is sufficient to conduct the research. The information in the questionnaire is an important component in planning research methods for data collection purposes Cresswell (2005). The questionnaire used in this study is the research questions because he allowed the collection or data that is reliable and valid in the sample reasonable and cheap in the set (Anderson \& Arsenault, 2002). The modified questionnaire was tested their validity through face validity and content 
validity.

The validity of a test refers to the extent to which something that the test measures what it is supposed to be measured Tuckman (1978), Alias (1992), Gay and Arisian (2000), Rubin and Babbie (2001), something the test or questionnaire is said to have high validity if the degree of ability to measure what should he measure is high. The validity of the test is also important in all forms of research and all kinds of tests and measurements. Measurement trust by using Cronbach alpha formula. When the reliability coefficient, the larger the resulting questionnaire means that this questionnaire has high reliability. Cronbach's Alpha reliability coefficients usually ranges between 0 and 1 Gilem and Gilem (2003).

Leadership questionnaire dean is an adaptation of Avolio et al, (1999) on the leadership consists of 23 four dimensions: (1) Charisma (2) Consideration of Individuals (3) Intellectual Stimulation (4) Motivation Inspiration. Questionnaires teacher performance is an adaptation of the questionnaire inventory that has been developed by Wan Syahril Ismail (2004) by taking 5 of 7 dimensions, the total questionnaire include: (1) planning of teaching (2) delivery, (3) the diversity of teaching methods (4) to meet the needs different and (5) evaluation and reporting. Culture Questionnaire study of cultural adaptation of the questionnaire study is adapted from the School Culture Elements questionaire by Cavanagh and Ramonoski (2005) with dimensions: (1) the value of education (2) emphasis on learning (3) Equation vision (4) teacher. Madrasah quality questionnaire adapted from the theory of input-process-output model of school achievement or school effectively raised by Edmond (1987), Shahril Marzuki (1997) with dimensions: (1) Leadership headmaster strong and effective, (2) school climate healthy and conducive, (3) Emphasis on basic skills, (4) high expectations for academic performance Learners.

\section{Results and Discussion}

\subsection{Research Result}

4.1.1 Stage Leadership Principals, Teachers Performance, Learning Culture and Madrasah Quality

The findings show leadership charisma headmaster based indicators (mean $=19.25, \mathrm{SD}=3.4$ ), individual consideration indicator (mean=19.83, $\mathrm{SD}=3.9$ ), intellectual stimulation indicator (mean= 18.47, $\mathrm{SD}=4.1$ ), from this data indicator variable intellectual stimulation headmaster leadership got mean value scores high. Inspirational motivation indicator (mean $=15.28, \mathrm{SD}=3.6)$ and overall leadership headmaster (mean $=18.20$, $\mathrm{SD}=3.8$ ), thereby leadership variables headmaster has min value high scores. Data were analyzed using descriptive statistical methods are shown in Table 1.

Table 1. Distribution rate mean and standard deviations leadership principals Tsanawiyah South Jakarta District

\begin{tabular}{llllll}
\hline No & Indicator & N & Standar Deviations & Mean & Interpretation \\
\hline 1 & Charisma & 200 & 3.4 & 19.25 & High \\
2 & Individual consideration & 200 & 3.9 & 19.83 & High \\
3 & Intellectual stimulation & 200 & 4.1 & 18.47 & High \\
4 & Motivation Inspiration & 200 & 3.6 & 15.28 & High \\
Madrasah Principals Leadership & 200 & 3.8 & 18.20 & High \\
\hline
\end{tabular}

Table 1 shows the level of leadership Madrasah Tsanawiyah South Jakarta, the results of the calculation of the data showed the level of school leadership can be used for all items.

Overall planning indicator variable performance-based teacher's teaching (mean $=16.45, \mathrm{SD}=3.9$ ), delivery indicator (mean=16.52, $\mathrm{SD}=3.3$ ), teaching methods have a diversity indicator (mean $=15.85, \mathrm{SD}=3.8$ ), the indicators meet the different needs (mean $=15.17, \mathrm{SD}=3.9$ ), from this data to meet the needs of different indicator variable has a value of teacher performance scores average height. Indicators and reporting (mean= $15.80, \mathrm{SD}=3.8$ ), of indicator data assessment and reporting the value of average height and overall performance of teachers (mean=15.95, $\mathrm{SD}=3.7$ ). It has a variable value means high value of teacher performance. Data were analyzed using descriptive statistics are shown in Table 2. 
Table 2. Distribution rate mean and standard deviations teacher performance Tsanawiyah South Jakarta District

\begin{tabular}{llllll}
\hline No & Indicator & N & Standard Deviation & Mean & Interpretation \\
\hline 1 & Lesson planning & 200 & 3.9 & 16.45 & High \\
2 & Delivery & 200 & 3.3 & 16.52 & High \\
3 & Diversity of teaching methods & 200 & 3.8 & 15.85 & High \\
4 & Meets different needs & 200 & 3.9 & 15.17 & High \\
5 & Evaluation and reporting & 200 & 3.8 & 15.80 & High \\
& Teacher performance & 200 & 3.7 & 15.95 & High \\
\hline
\end{tabular}

Table 2 shows the level of performance teacher Madrasah Tsanawiyah of South Jakarta, the calculation results of the study's data show the level of performance is high madrasah teachers and satisfying for the entire item.

Cultural variables studied in this research to get the value of the indicator is based on the value of education (mean $=15.44, \mathrm{SD}=3.9)$, indicators emphasis on learning (mean=16.02, $\mathrm{SD}=3.6$ ), equation indicator vision $($ mean $=14.92, \mathrm{SD}=3.8)$, teacher indicator $($ mean $=15.80, \mathrm{SD}=4.2)$, of this data indicator variable teacher learning culture mean value high scores and overall learning culturehas (mean=15.54, $\mathrm{SD}=3.9$ ). Thus learning the cultural variables has scores mean high value. Data were analyzed using descriptive statistics are shown in Table 3.

Table 3. Distribution Levels Mean and Standard Deviation Cultural Learning Tsanawiyah South Jakarta District

\begin{tabular}{llllll}
\hline No & Indicator & N & Standard Deviation & Mean & Interpretation \\
\hline 1 & Value of education & 200 & 3.9 & 15.44 & High \\
2 & Emphasis on learning & 200 & 3.6 & 16.02 & High \\
3 & Match vision & 200 & 3.8 & 14.92 & High \\
4 & Teacher & 200 & 4.2 & 15.80 & High \\
& Cultural Learning & 200 & 3.9 & 15.54 & High \\
\hline
\end{tabular}

Table 3 shows the level of Madrasah Tsanawiyah learning cultureof South Jakarta, the results of calculations on the data of these studies indicate the level of higher learning cultureand madrasah are satisfactory for the entire item.

The last variable is the quality of the madrasah, the overall quality of the madrasah based indicators of leadership $($ mean $=16.38, \mathrm{SD}=3.8)$, school climate indicator $($ mean= $16.27, \mathrm{SD}=3.9)$, indicators skills the base (mean= $15.74, \mathrm{SD}=3.5$ ), indicators of academic achievement (mean=17.11, $\mathrm{SD}=3.2)$ and the overall quality of the madrasah (mean=16.37, $\mathrm{SD}=3.6$ ). Thus the value of the variable quality of the madrasah has mean scores were high. Data were analyzed using descriptive statistics are shown in Table 4.

Table 4. Distribution levels mean and standard deviation Madrasah Quality Tsanawiyah South Jakarta District

\begin{tabular}{llllll}
\hline No & Indicator & N & Standard Deviation & Mean & Interpretation \\
\hline 1 & leadership & 200 & 3.8 & 16.38 & High \\
2 & School climate & 200 & 3.9 & 16.27 & High \\
3 & Basic Skills & 200 & 3.5 & 15.74 & High \\
4 & Academic Achievement & 200 & 3.2 & 17.11 & High \\
& Madrasah Quality & 200 & 3.6 & 16.37 & High \\
\hline
\end{tabular}

Table 4 shows the level of quality of the Madrasah Tsanawiyah of South Jakarta, the results of calculations on the data of these studies showed a high level of quality and madrasah are satisfactory for the entire item.

\subsubsection{Relationship on the Quality Leadership Principals Madrasah}

The second research issue is whether there is a relationship to the quality of leadership headmaster madrasah. To answer the second research question, the information obtained from the questionnaires and quality leadership madrasah madrasah teachers answered by 200 people, through the Pearson correlation analysis. Pearson correlation analysis gives the Pearson correlation coefficient $r$ form is positive $(+)$ or negative $(-)$ to indicate the relationship between the variables, the coefficient values between 0:00 to 1:00 also means the strength of the 
relationship, the 'rule of thumb' way Johnson and Nelson (1986) is used to describe the strength of the correlation that has no relation $(0.00)$, very low, low, simple, very tall and perfect correlation (1.00).

The findings of the study the relationship between the leadership of the headmaster and the quality of madrasah is displayed in the form of a correlation matrix as shown in Table 5, namely:

Table 5. Relationship between leadership principals on the quality of Madrasah

\begin{tabular}{llllll}
\hline $\begin{array}{l}\text { Madrasah Quality } \\
\text { Leadership of the Headmaster }\end{array}$ & Leadership & $\begin{array}{l}\text { School } \\
\text { climate }\end{array}$ & Basic Skills & $\begin{array}{l}\text { Quality } \\
\text { Academic }\end{array}$ & $\begin{array}{l}\text { Performance } \\
\text { Madrasah }\end{array}$ \\
\hline charisma & 0.044 & 0.071 & 0.025 & 0.081 & 0.031 \\
Individual consideration & $0.358^{* *}$ & 0.130 & 0.008 & 0.101 & $0.259^{* *}$ \\
Intellectual stimulation & $0.390^{* *}$ & $0.422^{* *}$ & $0.147^{*}$ & 0.057 & $0.444^{* *}$ \\
Motivation Inspiration & 0.061 & 0.136 & $0.674^{* *}$ & $0.277^{* *}$ & $0.464^{* *}$ \\
School principals & $0.355^{* *}$ & $0.314^{* *}$ & $0.334^{* *}$ & $0.143^{*}$ & $0.487^{* *}$ \\
$\mathrm{~N}$ & 200 & 200 & 200 & 200 & 200 \\
\hline
\end{tabular}

* significant at the level of $<0.05$

** significant at the level of $<0.01$

Based on the results of Table 5 above, the relationship headmaster leadership with significant quality and sturdy madrasah are shown $(\mathrm{r}=0.487)$ and was followed by consideration of individual indicators with leadership $(\mathrm{r}=$ $0.358)$, indicators of consideration individuals with quality madrasah $(\mathrm{r}=0.259)$ an indicator of intellectual stimulation with leadership $(\mathrm{r}=0.390)$, intellectual stimulation with school climate $(\mathrm{r}=0.442)$, intellectual stimulation with basic skills $(r=0.147)$, indicators of the quality of intellectual stimulation madrasah $(r=0.444)$, inspirational motivation indicators with basic skills $(\mathrm{r}=0.674)$ an indicator of motivation inspiration with academic achievement $(\mathrm{r}=0.227)$, indicators of motivation inspiration with the quality of madrasah $(\mathrm{r}=0.464)$ as well as the leadership of the headmaster with leadership ( $\mathrm{r}=0.355)$, the leadership of dean madrasah school climate $(r=0.314)$, the leadership of the headmaster with basic skills $(r=0.334)$ and the leadership of headmaster with academic achievement $(r=0.143)$. Thus, it can be concluded that there is a significant relationship between the leadership of the headmaster and the quality of madrasah with floor $<0.05$.

No significant relationship was shown by the indicator charisma with leadership $(r=0.044)$, with the charisma indicator of school climate $(\mathrm{r}=0.071)$, charisma with basic skills $(\mathrm{r}=0.025)$, charisma with academic achievement $(\mathrm{r}=0.081)$, charisma with the quality of madrasah $(\mathrm{r}=0.031)$.

Consideration of individual indicators with school climate $(\mathrm{r}=0.130)$, consideration of the individual with basic skills $(r=0.008)$, consideration of individuals with academic achievement $(r=0.101)$, so similarly indicator intellectual stimulation with academic achievement $(\mathrm{r}=0.057)$ an indicator of motivation inspiration with leadership ( $\mathrm{r}=0.061)$, inspirational motivation with school climate $(\mathrm{r}=0.136)$.

\subsubsection{Teacher Performance Relationship with Quality Madrasah}

The third research issue is whether there is a relationship with the teacher achievement madrasah quality. To answer the research questions, the information obtained from the questionnaires achievement and teacher quality madrasah teachers answered by 200 people, through the Pearson correlation analysis. The findings of the study the relationship between achievement madrasah teachers with the quality described in Table 6 are: 
Table 6. Relationship between teacher performance With Quality Madrasah

\begin{tabular}{llllll}
\hline \multicolumn{1}{c}{ Madrasah Quality } & Leadership & $\begin{array}{l}\text { School } \\
\text { Climate }\end{array}$ & Basic skill & $\begin{array}{l}\text { Academic } \\
\text { Achevement }\end{array}$ & $\begin{array}{l}\text { Madrasah } \\
\text { Quality }\end{array}$ \\
Teacher Performance & & & & & $0.195^{* *}$ \\
lesson planning & $0.272^{* *}$ & 0.024 & 0.125 & 0.035 & 0.029 \\
delivery & 0.107 & 0.110 & 0.058 & $0.21^{* *}$ & $0.196^{* *}$ \\
Diversity of teaching methods & $0.229^{* *}$ & 0.104 & 0.047 & $0.76^{* *}$ & $0.288^{* *}$ \\
Meet the needs of different & $0.145^{* *}$ & $0.199^{* *}$ & $0.238^{* *}$ & 0.103 & $0.319^{* *}$ \\
Evaluation and reporting & 0.095 & 0.107 & $0.328^{* *}$ & $0.257^{* *}$ & $0.352^{* *}$ \\
\hline Teacher Performance & $0.288^{* *}$ & 0.117 & $0.270^{* *}$ & $0.167^{*}$ & \\
\hline
\end{tabular}

** significant at the level of $\mathrm{p}>0.01$

* significant at the level of $\mathrm{p}>0.05$

Based on the results of Table 6 above, found no significant relationship and solid on the floor $p>.05$ between teacher performance and the quality of the madrasah in the South Jakarta District, significant relationships and sturdy simple also shown by the planning of teaching and leadership $(\mathrm{r}=0.272)$, indicators of planning and quality teaching madrasah $(\mathrm{r}=0.195)$, the next significant correlation and simple delivery also shown by indicators and indicators of academic performance $(\mathrm{r}=0.211)$, the diversity of methods of teaching and leadership $(r=0.229)$, diversity of teaching methods and the quality of madrasah $(r=0.196)$. Thus, it can be concluded that there is a significant correlation with the quality of teacher performance madrasah with floor $<0.05$. Significant correlation and simple also indicated by Meet the needs of different groups and indicators of leadership ( $\mathrm{r}=0.145)$, indicators of school climate $(\mathrm{r}=0.199)$, indicators meet the different needs and basic skills $(\mathrm{r}=0.238)$, indicators meet the different needs and quality of madrasah $(\mathrm{r}=0.288)$. Furthermore, the absence of a significant relationship also indicated by the assessment and reporting and indicators of basic skills $(\mathrm{r}=0.328)$ and reporting assessment indicators and indicators of academic performance $(\mathrm{r}=0.257)$, evaluation and reporting and the quality of the madrasah $(\mathrm{r}=0.319)$.

No significant relationship was shown by the indicator teaching plan with the school climate $(r=0.024)$, indicators of planning teaching basic skills $(\mathrm{r}=0.125)$, the planning of teaching with academic achievement $(\mathrm{r}=$ $0.035)$, with the delivery of leadership ( $\mathrm{r}=0.107)$, with the delivery of school climate $(\mathrm{r}=0.110)$, with the delivery of basic skills $(\mathrm{r}=0.058)$, delivery with academic achievement $(\mathrm{r}=0.021)$ and delivery with quality madrasah $(r=0.029)$, indicators of diversity of teaching methods with the school climate $(r=0.104)$, the indicator diversity of teaching methods with basic skills $(\mathrm{r}=0.047)$ and indicators of academic performance $(\mathrm{r}=0.076)$ the indicators meet the different needs of the academic achievement $(\mathrm{r}=0.103)$, as well as evaluation and reporting indicators with indicators of leadership $(\mathrm{r}=0.097)$, indicators of school climate $(\mathrm{r}=0.107)$ and indicators of the quality of the delivery of madrasah $(\mathrm{r}=0.029)$.

\subsubsection{Relationship Between Learning Cultural on the Quality of Madrasah}

The fourth research issue is whether there is a relationship between the learning culture on the quality of madrasah. To answer the fourth research question, the information obtained from a culture of learning and quality questionnaire answered by 200 madrasah teachers, through the Pearson correlation analysis, the research findings on the relationship between learning cultural and madrasah quality, described in the form of a correlation matrix as shown in Table 7, namely:

Table 7. Relationship between cultural learning with Madrasah Quality

\begin{tabular}{llllll}
\hline Madrasah Quality & Leadership & $\begin{array}{l}\text { School } \\
\text { Climate }\end{array}$ & Basic Skill & $\begin{array}{l}\text { Academic } \\
\text { Performance }\end{array}$ & $\begin{array}{l}\text { Madrasah } \\
\text { Quality }\end{array}$ \\
\hline Eearning Culture & & & & 0.109 & $0.179^{*}$ \\
Education Value & $0.138^{*}$ & 0.068 & 0.116 & 0.003 & $0.207^{* *}$ \\
Emphasis On Learning & $0.331^{* *}$ & $0.138^{*}$ & 0.060 & 0.082 & $0.342^{* *}$ \\
Match Vision & $0.167^{*}$ & $0.236^{*}$ & $0.324^{* *}$ & $0.385^{* *}$ & $0.324^{* *}$ \\
Teacher & 0.055 & 0.022 & $0.362^{* *}$ & $0.252^{* *}$ & $0.483^{* *}$ \\
Learning Culture & $0.277^{* *}$ & $0.187^{* *}$ & $0.339^{* *}$ & & \\
** significant at the level of $\mathrm{p}<0.01$ & & & &
\end{tabular}


Based on the results of Table 7 above, found a significant relationship at the level of $p<.05$ between the culture of learning and the quality of the madrasah in the South Jakarta District with values $(r=0.483)$. A significant correlation and simple also is shown by respondents to the indicator value of education with the leadership is shown by the value of the correlation $(r=0.138, p<.05)$, the value of the quality of madrasah education with values $(\mathrm{r}=0.179)$, an indicator of learning with an emphasis on leadership is $(\mathrm{r}=0.331)$, the emphasis on learning with school climate is $(r=0.138)$ and the quality of the madrasah $(r=0.207)$. Further indicators of vision with the leadership equation $(r=0.167)$, equating vision with school climate $(r=0.236)$, equating indicator vision with basic skills $(\mathrm{r}=0.324)$ and equalization vision with the quality of madrasah $(\mathrm{r}=0.342)$, for indicators of teachers with basic skills $(r=0.385)$, indicators of teachers with academic achievement $(r=0.385)$ and teachers with quality madrasah $(\mathrm{r}=0.324)$. There relationship quality indicators madrasah to learn the culture can be seen from the indicators of leadership with a learning culture $(\mathrm{r}=0.277)$, indicators of school climate with a learning culture $(\mathrm{r}=0.187)$, indicators of basic skills with a learning culture $(\mathrm{r}=0.339)$, academic achievement with a learning culture that is visible from the value $(\mathrm{r}=0.255)$. Thus, it can be concluded that there is a significant correlation with the quality of learning culturemadrasah with floor $<0.05$.

Furthermore, the absence of a significant relationship also indicated by a learning culture with quality madrasah through several indicators, as seen from the indicator value of education with school climate $(r=0.068)$ an indicator of the value of education with basic skills $(r=0.116)$ an indicator of the value of education and academic performance indicators $(\mathrm{r}=0.109)$. There is no relationship was also shown by the indicator with an emphasis on learning basic skills $(\mathrm{r}=0.060)$, as well as academic performance indicators $(\mathrm{r}=0.003)$, equating indicator vision seen in relation to academic achievement visible indicator of value $(\mathrm{r}=0.082)$, while the indicator of the absence of the teacher also has a relationship with the leadership of the indicator it $(\mathrm{r}=0.055)$, as well as school climate with values $(\mathrm{r}=0.022)$. Can be concluded that the culture of learning with quality indicators madrasah have a relationship in the absence of some indicators between these two variables, but the overall variable has a high enough relationship.

4.1.5 Relationship Between Leadership Principals, Teachers Performance and Learning Culture on the Quality of Madrasah

To analyze about 5 studies using stepwise regression analysis, the question in this research is that there is no positive correlation leadership headmaster, teacher performance and learning culture of the quality of madrasah. To perform a multivariate regression analysis using stepwise method, first performed a correlation analysis as shown in Table 8.

Table 8. Correlation between variables

\begin{tabular}{lllll}
\hline Model & $\mathrm{R}$ & R Square & Adjusted R Square & Std. Error of the Estimate \\
\hline 1 & $.487^{\mathrm{a}}$ & .238 & .234 & 8.842 \\
2 & $.572^{\mathrm{b}}$ & .327 & .320 & 8.330 \\
3 & $.596^{\mathrm{c}}$ & .355 & .345 & 8.172 \\
\hline a. Predictors: (Constant), $\mathrm{X}_{1}$ & & \\
b. Predictors: (Constant), $\mathrm{X}_{1}, \mathrm{X}_{3}$ \\
c. Predictors: (Constant), $\mathrm{X} 1, \mathrm{X} 3, \mathrm{X} 2$
\end{tabular}

From Table 8 it was found that the correlation value on leadership variables for 0487 , with the determination of the correlation value of 0.238 . This means that approximately $23.8 \%$ of madrasah quality factor can be explained by the leadership of the headmaster. As added by cultural variables studied the correlation value of 0572 with a value of determining the correlation of 0327 which shows the percentage to $32.7 \%$, which means that $57.2 \%$ of the factors that affect the quality of madrasah can be explained by the headmaster leadership and learning culture, as well as the value of the variable correlation headmaster leadership, culture of learning and teacher performance for 0596 with a value of determination of 0.355 if means that $35.5 \%$ of variable quality can be explained by the leadership madrasah headmaster, a culture of learning and teacher performance. While the rest is explained by other variables. Multiple regression calculations with variable data using stepwise method can be seen in Table 9. 
Table 9. Multivariate regression using stepwise method

\begin{tabular}{|c|c|c|c|c|c|c|}
\hline & & \multicolumn{2}{|c|}{ Unstandardized Coefficients } & Standardized Coefficients & \multirow[b]{2}{*}{$\mathrm{t}$} & \multirow[b]{2}{*}{ Sig. } \\
\hline \multicolumn{2}{|c|}{ Model } & B & Std. Error & Beta & & \\
\hline \multirow[t]{2}{*}{1} & (Constant) & 50.344 & 3.995 & & 12.603 & .000 \\
\hline & $\mathrm{X}_{1}$ & .347 & .044 & .487 & 7.853 & .000 \\
\hline \multirow[t]{3}{*}{2} & (Constant) & 36.258 & 4.666 & & 7.771 & .000 \\
\hline & $\mathrm{X}_{1}$ & .276 & .044 & .388 & 6.290 & .000 \\
\hline & $\mathrm{X}_{3}$ & .237 & .046 & .315 & 5.108 & .000 \\
\hline \multirow[t]{4}{*}{3} & (Constant) & 30.276 & 5.007 & & 6.047 & .000 \\
\hline & $\mathrm{X}_{1}$ & .256 & .044 & .359 & 5.869 & .000 \\
\hline & $\mathrm{X}_{3}$ & .201 & .047 & .266 & 4.249 & .000 \\
\hline & $\mathrm{X}_{2}$ & .122 & .042 & .181 & 2.948 & .004 \\
\hline
\end{tabular}

Dependent Variable: Y

From Table 9 above shows that the calculation of multivariate regression using stepwise regression on the first model of 0347 for the variables a1 $\mathrm{X}_{1}$ (school principals) with a constant value of 50344 , in both directions regression model was 0.276 for the variable a1 $\mathrm{X}_{1}$ (school principals' leadership), a2 equal to 0.237 for the variable $\mathrm{X}_{3}$ (learning culture). In the third regression model was 0.256 for the variable a1 $\mathrm{X}_{1}$ (leadership school principals), a2 direction of 0.201 for the variable $X_{3}$ (learning culture), the direction of a3 0122 for variable $X_{2}$ (teacher performance). The final form of multivariate regression between independent variables with the dependent variable can be described by the regression equation $\mathrm{y}=30276+0.256 \mathrm{X}_{1}+0.201 \mathrm{X}_{3}+0.122 \mathrm{X}_{2}$.

Before being used for predictive purposes, this regression equation regression testing should be performed interests. To determine the degree of importance of the multiple regression equation, $F$ test and the results are presented in Table 10 as follows:

Table 10. Multiple linear regression analysis of variance $\hat{Y}=30.276+0.256 X_{1}+0.201 X_{3}+0.122 X_{2}$

\begin{tabular}{|c|c|c|c|c|c|c|}
\hline Model & & Sum of Squares & $\mathrm{df}$ & Mean Square & $\mathrm{F}$ & Sig. \\
\hline \multirow[t]{3}{*}{1} & Regression & 4822.066 & 1 & 4822.066 & 61.677 & $.000^{\mathrm{a}}$ \\
\hline & Residual & 15480.154 & 198 & 78.183 & & \\
\hline & Total & 20302.220 & 199 & & & \\
\hline \multirow[t]{3}{*}{2} & Regression & 6632.428 & 2 & 3316.214 & 47.791 & $.000^{\mathrm{b}}$ \\
\hline & Residual & 13669.792 & 197 & 69.390 & & \\
\hline & Total & 20302.220 & 199 & & & \\
\hline \multirow[t]{3}{*}{3} & Regression & 7212.726 & 3 & 2404.242 & 36.001 & $.000^{\mathrm{c}}$ \\
\hline & Residual & 13089.494 & 196 & 66.783 & & \\
\hline & Total & 20302.220 & 199 & & & \\
\hline \multicolumn{7}{|c|}{ a. Predictors: (Constant), $X_{1}$} \\
\hline \multicolumn{7}{|c|}{ b. Predictors: (Constant), $\mathrm{X}_{1}, \mathrm{X}_{3}$} \\
\hline \multicolumn{7}{|c|}{ c. Predictors: (Constant), $\mathrm{X}_{1}, \mathrm{X}_{3}, \mathrm{X}_{2}$} \\
\hline \multicolumn{7}{|c|}{ d. Dependent Variable: Y } \\
\hline
\end{tabular}

Based on multiple regression analysis of variance in Table 10 above. It is known as the first model with independent variables $X_{1}$ (leadership school principals) $F$ value price of 61.677 with sig $=0.000$, the second model with independent variables $X_{1}$ (school principals' leadership) and $X_{3}$ (learning culture) $F$ value price of 47.791 with sig $=0.000$, the third model with independent variables independent variables $X_{1}$ (school principals' leadership) and $X_{3}$ (learning culture) and $X_{2}$ (performance teacher) $F$ value of 36.001 with sig $=0.000$, it can be concluded multiple regression $\mathrm{y}=30276+0.256 \mathrm{X}_{1}+0.201 \mathrm{X}_{3}+0.122 \mathrm{X}_{2}$, very significant. These findings prove 
that there is a relationship between school leadership, teacher performance and learning culture together to quality schools.

\subsection{Discussion}

The discussion begins with a high level of contributory factor principals, teacher performance and learning culturein improving the quality of Madrasah Tsanawiyah in Jakarta South. In discussing the relationship between the principals, the overall level of leadership influence is very strong or high levels in madrasah. Results is showed a significant relationship and strong school leadership with the quality of madrasah.

The findings of this study support the findings Cheng (1993) study in which he found in studies of effective schools have good leadership, directed to the designated goal of increasing efficiency, explain the role, involvement of all members of the organization and have a range of high achievement in academics. Leadership enable educational institutions to design something in the long term that will achieve good organization. An excellent and effective school principals described madrasah schools are able to manage and administer efficiently and effectively Yunus (2005). This statement was supported by Width (2002), which states that a successful school depends on the leadership and management abilities in school. Leadership is crucial to the performance of teachers and the learning culturein improving the quality of madrasah alsagoff South Jakarta, because it all relates to the influence of effective leadership.

Many studies have found that $50 \%$ of school principals is to interact directly with teachers and students. Principals work appears on the decisions to be better (Sergiovanni, 1991). In the management of the school or school principals require effective leadership, effective leadership helped by good behavior. Study by Marzuki (1997) who pointed out that the success of a particular school in the academic field a lot depends on the leadership of the teachers in instructional leadership and school climate conditions are good and positive. From the study found a significant relationship exists between performance and sound quality of teachers and school in madrasah Jakarta south. Ghani (2008) states that the success of a school depends heavily on teacher performance factors, and factors in supporting students to teacher performance factors. Performance of teachers who achieve $80 \%$ was also found in a study which stated that: "The general picture is the teacher learning achievement level (79.81\%) and is in the category of being" (Zulpen, 2005).

Husdarta (2007) achievements have become a necessity for a teacher, because the performance of teachers in teaching the most important part in supporting the creation of effective educational process tertama in building discipline and the quality of student learning outcomes. The study also showed a significant relationship between the culture of learning and the quality of madrasah Jakarta South. Supriadi (1998) which states that: "Closely related to the quality of school principals with various aspects of school life such as school discipline, school culture and climate of declining student naughty behavior".

Cascio (2002) factors that affect the quality and performance are 1) the participation of human resources, 2) career development, 3) communication, health and safety, 4) conflict resolution, 5) good incentive, 6) pride. Madrasah teachers in the state Tsanawiyah agree that school leadership is often reminiscent of the teachers and students about safety at school. This study supports the findings Marzuki (1997), who found an effective school climate and school results when the atmosphere is safe, beautiful, and happy and enough space.

For that school organization to maintain compatibility and compatibility with the learning cultureof the school environment that is constantly changing. Climate change education has created identify methods and strategies that can improve the quality of madrasah.

Multiple correlation of test results, the final model of multiple regression analysis using stepwise method was found in this study is very significant. These findings prove that there is a positive relationship madrasah principals, teacher performance and learning culturetogether on quality madrasah.

It must be recognized that the teacher is a key factor in the educational process. Although complete and advanced education facilities but if not followed by the presence of qualified teachers. It is impossible to inflict maximum learning process. (Cohen, 2003).

The results of this study are consistent with submitted by Webber (1971), Edmonds (1979), which states that effective schools, teachers placed greater emphasis and focus on the mastery of skills, this finding is also consistent with the finding Farihah (2012) which says with increasing teacher performance can ultimately improve school achievement of organizational goals.

\section{Conclusion}

Based on the findings note that the leadership of headmaster, performance madrasah and learning culture has a positive and significant relationship to the quality of madrasah both individually and collectively. 
There are was a significant correlation between the quality of leadership headmaster madrasah, leadership headmaster in the high category. The relationship between the two variables based analysis provides information that in the event of an increase in the headmaster's leadership will be followed by an increase in the quality of the madrasah. The higher leadership of the headmaster, the higher the quality of the madrasah.

Someone dean practice leadership styles of teaching and administrative leadership to improve the quality of the madrasah. According Mortimore (1995) Head and teachers should work together to strengthen teaching and learning for childbirth effectiveness, principals as teaching supervisor role ensuring teachers teaching can be carried out efficiently and effectively.

Leadership headmaster is very important in an educational institution including madrasah, this is because the headmaster had a very big role in the management of madrasah, madrasah resources. The role of a leader is as a direction and purpose in the future (direct setter), agent of change (change agents), negotiator (spokes person), and as a mentor (coach). There is a significant relationship of teacher performance variable to variable quality of madrasah. The relationship between the two variables based analysis provides information that in the event of an increase in the teacher's performance will be followed by an increase in the quality of madrasah. So the higher the teacher's performance, the higher the level of quality of the madrasah.

The learning process will take place properly if it is supported by teachers who have the competence and high performance. Teachers who have a good performance will improve the morale and motivation of students to learn better, which in turn will improve the quality of learning. learning process running with the maximum, effective and efficient, this is due to the innovation and creativity from teachers, thus improving the quality of the good in the madrasah. There is a positive relationship to the quality of learning culture madrasah. The relationship between the two variables in the analysis based either category, provide information that in the event of an increase in the culture of learning will be followed by an increase in the quality of madrasah, so the higher the higher the quality of learning culture madrasah.

Learning cultural to be a philosophy that is based on the view as inherent value, for the creation of a conducive learning culture and positive, in madrasah must create cherished values shared by all citizens of madrasah good social values, morals, decency, morality, and spiritually in the organization. Madrasah need teachers who have compassion for all students and residents madrasah without favoritism, so as to motivate students in the learning process.

Creating a learning culture in the madrasah can be created with the cooperation and partnership between citizens with citizens madrasah Islamic schools, madrasah citizens and parents and other education stakeholders. So it can be concluded that the leadership of headmaster, teacher performance and learning culture has a major role to the high or the low quality of the madrasah. Low quality madrasah can be caused by poor leadership headmaster, teacher performance and learning culture at Madrasah.

\section{Suggestion}

This review describes the school leadership, teacher performance and learning culture in improving quality in madrasah the South Jakarta District. In addition there is the view of some researchers that the performance of teachers, learning culture. The quality has nothing to do with the effectiveness of the madrasah Islamic schools. Although the management and training has been given to the offender, the training is more likely to management madrasah and not about how to manage human capital resources. Therefore, the principals should be given retraining or short courses effectively in the areas of leadership madrasah, teaching leadership. They can become effective leaders rated madrasah and also provide guidance and point the way to the teachers for effective teaching methods.

Headmaster as a leader is responsible for all activities of madrasah role as coordinator and supervisor, as an administrator. He was responsible for achieving educational goals effectively and efficiently, as a leader. He was responsible for developing the quality of teaching at the school, through the provision of assistance to the professional development teacher. Dean must always pay attention to the teacher to maintain performance results that have been achieved with a pretty good value in teaching-learning activities. Improving the quality of madrasah not only make improvements in the quality of teachers in implementing the learning process but also necessary and important followed by school leadership that leads to an increase in the quality of madrasah. In this case, the principal's leadership and the local education department to provide supervision and training activities for madrasah teachers and accomplice in performing their duties.

Culture of learning at the school must be really useful for improving the quality of teaching and learning process. Learning culture can be created with the good cooperation between citizens madrasah, follow the madrasah 
management effective. Headmaster as a leader implement madrasah management by providing a high motivation to residents in the teaching-learning madrasah, so as to create a culture of high learning.

Ministry of Education: South Jakarta Office of the Ministry of Education to monitor and control the learning success of State junior madrasah students to conduct periodic evaluations. Making teacher development programs to improve the management of the class together with the emphasis on improving the quality of madrasah. The teacher development can improve the professionalism, a teacher will make efforts to be able to produce good learning process, one of which is to improve the culture of learning and provide good learning motivation to students at the school.

Principals: Head madrasah must carry out his duties as leader of teaching by creating a program to improve the ability and insight to teachers by providing training and coaching as well as perform in accordance with the planned programs routinely and regularly. Program and construction activities will be evaluated on a regular basis to see the development of capabilities and quality of teachers. The assessment provides an overview of teacher performance and the ability of teachers in the learning process, therefore the training and coaching programs for teachers will be refined so that teachers can and can improve performance. The cooperation undertaken by the principal at the school with various stakeholders in improving the quality madrasah Islamic schools such as school committees and community. Along with stakeholders, in addition to the headmaster as a leader should pay more attention to teachers and students in improving the quality of the madrasah and able to assist in solve problems, be an example for teachers and students.

Teacher: Teachers are examples of students, therefore, teachers are required to work as a professional educator, capable of improving student achievement, in the learning process in the classroom, teachers should be sensitive and attentive to the condition of the student, able to stimulate students to be creative in learning. Teacher continues to improve his work with his own efforts to improve their quality (knowledge, skills, attitudes) with the mastery of science and technology and to improve both social intelligence, moral, emotional and spiritual.

\section{References}

Ahmad, R. H. (2003). Kepemimpinan dan kepengetuaan: Strategi dan pendekatan di alaf baru. Pemimpin: Jurnal Institut Pengetua.

Anderson, G., \& Arsenault, N. (2002). Fundamentals of Educational Research (Teachers Library). Philadelphia: The Falmer Press.

Avolio, B., Bass, B. M., \& dan Jung, D. I. (1999). Re-Examining The Components Of Transformasional And Transactional Leadership Using The MLQ. Journal of Occupational and Organizational Psychology, 72(4), 441-463. http://dx.doi.org/10.1348/096317999166789

Baba, A. B. (1992). Statistik Penyelidikan Dalam Pendidikan dan Sains Sosial. Bangi: Universiti Kebangsaan Malaysia.

Babbie, E. (2001). The practice of social research (9th ed.). Belmont, CA: Wadsworth/Thomson Learning.

Bafadhal, I. (2003). Manajemen Mutu Sekolah Dasar Dari Sentralisasi Menuju Desentralisasi. Jakarta: Bumi Aksara.

Basterfield. (2003). Total Quality Management. Bangladesh: Buthan.

Blandford, S. (2004). Profesional Development in Schools Manual. London: Financial Times Management.

Bolman, L., Bloch, H. W., \& Granell, E. (1999). Versatile leadership: A comparative analysis of reframing in Venezuelan managers. Kertas kerja yang dibentangkan di Persidangan World Wide Bilingual di Universiti Madrid, Sepanyol. (Mkst 1- 20 atas talian)

Cascio, W. (2002). Managing Human Resources: Productivity, Quality of Work Life, Profits. New Jersey: McGraw-Hill.

Cavanagh \& Dellar. (2000). School Culture: A Quantitative Perspective on a Subjective Phenomenon. Australia.

Cavanagh, R. F., \& Romanosky, J. (2005). Squential Application of Research, Clasical and Structure Equation Modelling Technique to Investige Elementry School Classroom Learning Culture. In R. F. Waugh (Ed.), Frontier in Educational Psycology. New York: Nova Science Publisher.

Cheng, Y. C. (1993). Profiles of organizational culture and effective schools. School Effectiveness and School Improvement, 4(2), 85-110. http://dx.doi.org/10.1080/0924345930040201

Creswell, J. W. (2005). Educational Research: Planing, Conducting, and Evaluating Quantitative and 
Qualitative Research (2nd ed). New Jersey: Merrill Prentice Hall.

dan Tanjung, A. (2003). Manajemen Motivasi. Jakarta: PT. Grasindo.

Edmonds, R. (1979). Effective school for the urban poor. Educational Leadership, 37(1), 15-27.

Edmund. (1987). Transformation. New York City: Leisure Books.

Fadjar, M. (1998). Madrasah dan Tantangan Modernitas. Bandung: Mizan.

Fullan, M. (2002). Association for Supervision and Curriculum Developmen. Educational Leadership. EBSCO Publishing.

Gay. L. R., \& Airasian, P. (2000). Educational Research: Competencies for Analysis and Aplication (6th ed.). New Jersey: Merrill.

Ghani, M. F. A. (2008). Pembentukan Model keberkesanan Dan Penambahbaikan Sekolah di Malaysia. Universiti Malaya, Kuala Lumpur.

Gibson. (2003). Organisasi: Perilaku, Struktur, dan Proses. Jakarta: Erlangga.

Gilem, A. J., \& Gilem, R. R. (2003). Calculating, Interpreting, and Reporting Cronbach's Alpha Reability Coefficient for Likert-type Scales. Midwest Research to Practice Conference in Adult, Continuing and Community Education.

Goetsch, D. (2006). Quality Management: Introduction to Total Quality Management for Production, Processing, and Services. New Jersey: Prentice Hall.

Halpin, A. W., \& Croft, D. B. (1963). The Organizational Climate of School. Chicago, Midwest Administration Centre, University of Chicago.

Husdarta. (2007). Faktor-faktor Yang Mempengaruhi Kinerja Guru Pendidikan Jasmani di Sekolah Dasar. Jurnal Mimbar Pendidikan.

Ishikawa, K. (2001). Introduction to Quality Control. California: University of California Press.

Kallison, J. M. (1986). Effects of lesson organization on achievement. American Educational Research Journal. http://dx.doi.org/10.3102/00028312023002337

Kast \& Rosenzweig. (1985). People and Organizational Management in Construction. Shamil Naoum.

Kerlinger, F. N. (2004). Asas-Asas Penelitian Behavioral. Yogyakarta: Gadjah Mada University Press

Koentjaraningrat. (2002). Pengantar Ilmu Antropologi. Jakarta: PT. Rineka Cipta.

Kumandar. (2007). Guru Profesional. Jakarta: Rajawali Pers.

Kusnadi. (2002). Masalah, kerja sama, konflik dan kinerja: kontemporer \& Islam. Surabaya: Taroda.

Lako, A. (2004). Kepemimpinan dan Kinerja Organisasi Isu Teori dan Solusi. Yogyakarta: Amara Books.

Marks, H. M., \& Printy, S. M. (2003). Principal Leadership and School Performance: An Integration of Transformational and Insrtruktional Leadership. Educational Administration Quarterly, 39(3), 370-397. http://dx.doi.org/10.1177/0013161X03253412

Marzuki, S. (1997). Kajian Sekolah Berkesan di Malaysia: Model Lima Faktor. Universiti Kebangsaan Malaysia, Bangi, Selangor, Malaysia.

Mortimore, P. (1995). Key Characteristic of Effective School. Kertas Kerja Dibentang pada Seminar Sekolah Efektif. Genting Highlands: IAB.

Mulyasa, E. (2002). Kurikulum Berbasis sekolah, Konsep, Strategi dan Implementasi. Bandung: Remaja Rosdakarya.

Mulyasa, E. (2003). Kurikulum Berbasis Kompetensi: Konsep, Karakteristik, dan Implementasi. Bandung: PT Remaja Rosdakarya.

Mulyasa, E. (2004). Menjadi Kepala Sekolah Professional. Bandung: Remaja Rosdakarya.

Mulyasa, E. (2006). Kurikulum Yang Disempurnakan. Bandung: Remaja Rosdakarya.

Mulyasa, E. (2007). Standar Kompetensi dan Sertifikasi Guru. Bandung: Remaja Rosdakarya.

Mulyasa, E. (2008). Standar Kompetensi dan Sertifikasi Guru. Bandung : Remaja Rosda Karya.

Oliver. (2008). Procedural Justice and trust: The Link in the Tranformational Leadership-Organizational 
Outcomes Relationship.

Piaw, C. Y. (2006). Kaedah dan Statistik Penyelidikan : Kaedah Penyelidikan. Kuala Lumpur: Mc Graw Hill.

Portin, B., Schneider, P., DeArmond, M., \& Gundlach, L. (2003). Making sense of leading schools: A study of the school principalship. Center on reinventing public education, Daniel J. Evans School of Public Affairs, University of Washington, Seattle.

Rahim, H. (2005). Madrasah dalam Politik Pendidikan di Indonesia. Jakarta: Logos.

Robbins, S. P. (2001). Organizational Behavior (9th ed.). New Jersey: Prentice Hall International.

Rubin, A., \& Babbie, E. (2001). Research Methods for Social Workers. California: Pacific Grove.

Salleh, L. M. (2002). Perancangan pendidikan peringkat sekolah dan IPT. Kuala Lumpur: Utusan Publication \& Distributor Sdn. Bhd.

Senge, P. M. et.al. (1990). The Fifth Disipline: The Art and Practice os the Learning Organization. New York: Doubieday.

Sergiovanni, T. (2001). The Principalship: A reflective practice (5th ed.). San Antonio, TX: Trinity Press.

Steenbrink, K. I. A. (1994). Pesantren Madrasah Sekolah: Pendidikan Islam Dalam Kaum Modern. Jakarta: LP3ES.

Subandi, A. (2010). Manajemen Kurikulum Berbasis Madrasah. Bandung: UNINUS. Disertasi.

Sugiarto et al. (2003). Teknik Sampling. Jakarta: Gramedia Pustaka Utama

Supriadi, D. (1998). Mengangkat Citra dan Martabat Guru. Yogyakarta: Adicita Karya Nusantara.

Supriatno, J. (1996). Penilaian Kinerja dan Pengembangan Guru. Yogyakarta : BPFE

Suratman, B. (2009). Hubungan Kompetensi Manajerial Kepala Sekolah, Ketersediaan Sarana Prasarana, Kapabilitas Mengajar Guru, dan Dukungan Orang Tua, dengan Prestasi Belajar Siswa SMP Negeri di Kota Surabaya. Disertasi, Program Studi Manajemen Pendidikan, Program Pascasarjana, Universitas Negeri Malang.

Taiguri, R., \& Litwin, G. (1998). Organizational Climate, Exploration of Concept. Boston : Harvard University.

Tilaar. (2002). Paradigma Baru Pendidikan Nasional. Jakarta: Rineka Cipta

Tuckman (1978). Conducting Educational Research. Trade Cloth.

Umi, F. (2012). Model Bersturktur Prestasi Kerja Guru di Trenggalek Jawa Timur, Indonesia. Universiti Malaya., Kuala Lumpur.

Undang-undang RI No. 14 tahun 2005 tentang Guru dan Dosen dan Peraturan Mendiknas Nomor 11 tahun 2005 beserta Penjelasannya. Bandung: Citra Utama.

Utami. M. (2003). Kreatifitas dan Keberbakatan: Strategi Mewujudkan Potensi Kreatif dan Bakat. Jakarta: Gramedia Pustaka Utama.

Uwes, S. (2004). Visi dan Pondasi Pendidikan (Dalam Perspektif Islam. Jakarta: Logos.

Weber, G. (1971). Inner - city children can be taught to read: four successful schools. Washington D. C: Council for Basic Education.

Wehmeier, S. (2000). Oxford Advanced Learner's Dictionary of Current English.

Witziers, B., Bosker, R. J., \& Kruger, M. L. (2003). Educational leadership and student achievement. The elusive search for an association. Educational Administration Quarterly, 39(3), 398-425. http://dx.doi.org/10.1177/0013161X03253411

Youngs, P., \& King, M. B. (2002). Principal leadership for professional development to build school capacity. Educational Administration Quarterly, 38(5), 643. http://dx.doi.org/10.1177/0013161X02239642

Yunus, J. N. (2005). Teori-Teori Pengurusan Pendidikan. Batu Cave, Selangor: Pustaka Salam.

Zulpen. (2005). Kontribusi Perilaku Kepemimpinan Kepala Sekolah dan Pelatihan Guru terhadap Kinerja Mengajarnya (Studi Deskriptif Analisis di SMAN Kota Pekan Baru). Bandung: Program Pascasarjana-UPI. 


\section{Copyrights}

Copyright for this article is retained by the author(s), with first publication rights granted to the journal.

This is an open-access article distributed under the terms and conditions of the Creative Commons Attribution license (http://creativecommons.org/licenses/by/3.0/). 